\title{
Unique biological affinity of the hanging coffin people in ancient China based on craniometry of two skulls from Yunnan province
}

\author{
XUEPING JI ${ }^{1}$, MITSUKO NAKAYAMA ${ }^{2}$, KANGXIN HAN ${ }^{3}$, XU LIU $^{1}$, HONG LIU $^{4}$, OSAMU KONDO ${ }^{5}$ \\ ${ }^{1}$ Yunnan Key Laboratory for Paleobiology, Yunnan Institute of Cultural Relics and Archeology, Kunming, China \\ ${ }^{2}$ Nihon University School of Dentistry at Matsudo, Matsudo, Japan \\ ${ }^{3}$ Institute of Archaeology, Chinese Academy of Social Sciences, Beijing, China \\ ${ }^{4}$ Yunnan Institute of Geography, Yunnan University, Kunming, China \\ ${ }^{5}$ Department of Biological Sciences, Graduate School of Science, The University of Tokyo, \\ Hongo 7-3-1, Bunkyo-ku, Tokyo, 113-0033 Japan
}

Received 5 August 2004; accepted 27 January 2005

\begin{abstract}
A higher density of evidence in terms of both temporal and geographical variation is needed for the understanding of the population history of East/Southeast Asia. We report here two skulls of the hanging coffin people from the ancient Tang dynasty of Yunnan province, China, and compare them with other Neolithic to modern human groups of East/Southeast Asia. The cranial series of the hanging coffin people can be regarded as a single population distinctive among the comparative samples. They share a low and wide face but exhibit variation in nasal root protrusion and alveolar prognathism. Evaluation of biological affinities based on multivariate craniometry indicates that the hanging coffin people are unique, being distant from modern mainland Asian groups and rather close to the Neolithic Zhenpiyan of south China. The peripheral position of the hanging coffin people relative to the mainland Asian groups appears to parallel the situation seen with modern Andaman islanders, or aboriginal Australians. This is interpreted as indicating the influence of a bottleneck effect in a locally isolated population within a more global trend of population history of East/Southeast Asian.
\end{abstract}

Key words: Tang dynasty, population history, East Asia, modern human diversity

\section{Introduction}

The hanging coffin burial is a mysterious funerary practice known in ancient southern Chinese minority populations. The dead were placed high on a cliff inside a wooden coffin or in a natural cleavage in the rock. The coffins appear as if they were hung in air on the wall. Based on ancient records, the earliest hanging coffins are known from the Wuyishan area in Fujian, and date back to more than 3000 years ago. The practice spread to the other provinces of China along the Yangtze River and its tributaries, and left its traces in the Southeast Asia and islands of the Pacific (Liu and Sun, 1996; Liu et al., 2001).

The 'Bo people', an ancient minority group of southeast China, has been assumed to be one of the most plausible owners of the hanging coffins. Their earliest appearance dates back to the 3rd century BC; they are assumed to have inhabited the area at and around the border of Sichuan, Yunnan, and Guizhou. It has been claimed that a 'Bo vassal kingdom' was established and governed in this region. The 'Bo people' disappeared from the literature after the end of

Collected Papers in Honor of Professor Emeritus Banri Endo: Commemoration of His Seventieth Birthday

* Corresponding author. e-mail: kondo-o@biol.s.u-tokyo.ac.jp phone: +81-3-5841-4482; fax: +81-3-3818-7547

Published online 22 April 2005

in J-STAGE (www.jstage.jst.go.jp) DOI: 10.1537/ase.040805 the Ming dynasty, and the hanging coffin burial practice faded away simultaneously. Therefore, the hanging coffins of south Sichuan and northeast Yunnan have been called the 'Bo people's hanging coffins' (Zhang, 1990).

However, these interpretations are based solely on documentary records. The biological affiliations of the Bo people or owners of the hanging coffins remain to be investigated. Were the owners of the hanging coffins of northeast Yunnan the Bo people? How did the Bo people appear and diminish, and who are their descendants? How did the owners hang the coffins on the cliffs? In Chinese archaeology and ethnology, there has been a long-termed controversy regarding these enigmas.

Recent field investigations have taken on some of these challenging issues. Human skeletal remains have been uncovered from three hanging coffin sites at Matangba, Washi, and Longma along the provincial border between Sichuan and Yunnan, where the relatively large-scaled and well-preserved hanging coffin sites are scattered (Liu and Sun, 1996; Liu et al., 2001). Skeletal remains from Matangba, Gong county in south Sichuan province, have been studied in a comparative framework of Chinese populations (Hu and Xiao, 1999a, b), indicating its close affinity with 'Zhuang Ren', the modern Zhuang people living in Guangxi province.

This paper describes another two skulls from Washi and Longma in Weixin county in northeastern Yunnan province, and compares them with modern populations from East/ 
Southeast Asia as well as with several Neolithic and/or historic archeological samples including the Japanese Jomon and Yayoi. The wide geographical range of comparison adopted in this study is intended to provide a new perspective on the ethnological affinities of the owners of the hanging coffins. That is to say, it will be possible to look at this issue from a broader perspective of temporal/geographical variation of modern people and population history of East/ Southeast Asia. We consider this study to be important at least in filling a temporal and geographical gap in our previous knowledge concerning the population history of East/ Southeast Asia.

\section{Materials and Methods}

\section{The Washi and Longma skulls}

In September 2000, the China Exploration of Hong Kong, the Yunnan Institute of Geography, and the Yunnan Institute of Cultural Relics and Archaeology conducted joint research for the preservation of hanging coffins at the site of Washi, which is located $37 \mathrm{~km}$ from Weixin city (GPS: $27^{\circ} 49^{\prime} 27^{\prime \prime} \mathrm{N}$ $104^{\circ} 46^{\prime} 49^{\prime \prime} \mathrm{E}$, altitude $615 \mathrm{~m}$ ) (Figure 1). A salvage excavation of three naturally destroyed coffins (WG1, WG2, WG3) unearthed a complete human skull and other postcranial bones of the same individual, together with a few wooden, bamboo, or textile relics from WG3. ${ }^{14} \mathrm{C}$ dating of the coffin wood samples resulted in a date of $1246 \pm 65$ BP for WG3.

Subsequently in April 2003, the Bang Productions Ltd. of Hong Kong, the Yunnan Institute of Cultural Relics and Archaeology, and the Yunnan Institute of Geography conducted an investigation of the Yanjin and Weixin counties for the purpose of making a television program for the Discovery Channel (USA). The investigation team found a new hanging coffin site at the natural cliffs of Jiudongyan, Longma, and Jiucheng, $50 \mathrm{~km}$ from Weixin city (GPS: $28^{\circ} 01^{\prime} 56.1^{\prime \prime} \mathrm{N} 105^{\circ} 00^{\prime} 16.2^{\prime \prime E}$, altitude $538 \mathrm{~m}$ ) (Figure 1). A human skull with a mandible and a few postcranial bones were found in a cleft on the cliff, where the surrounding coffin wood was completely decayed by weathering. ${ }^{14} \mathrm{C}$ dating was carried out for intact wood samples taken from another coffin in the vicinity of the human skeleton, giving a date of $1070 \pm 60 \mathrm{BP}$.

These skeletal remains are the object of the present study. We followed the methods outlined in Buikstra and Ubelaker (1994) for observations of the skull and estimation of sex or age at death. Because of the unavailability and incompleteness of postcranial bones, determination of sex and age was based on cranial superstructure and cranial suture closure patterns, respectively. Sex was diagnosed on the basis of morphology of sexually dimorphic areas of the cranium, such as the nuchal crest, mastoid process, supraorbital margin, glabellar region, and zygomatic process of the frontal bone, although there is wide variation in expressivity of each trait. Age at death was estimated on the basis of ectocranial suture closure (Meindl and Lovejoy, 1985). Cranial measurements were taken following Martin's (Bräuer, 1988) and Howells (Howells, 1973) methods, and facial flatness measurements following Yamaguchi (1973).

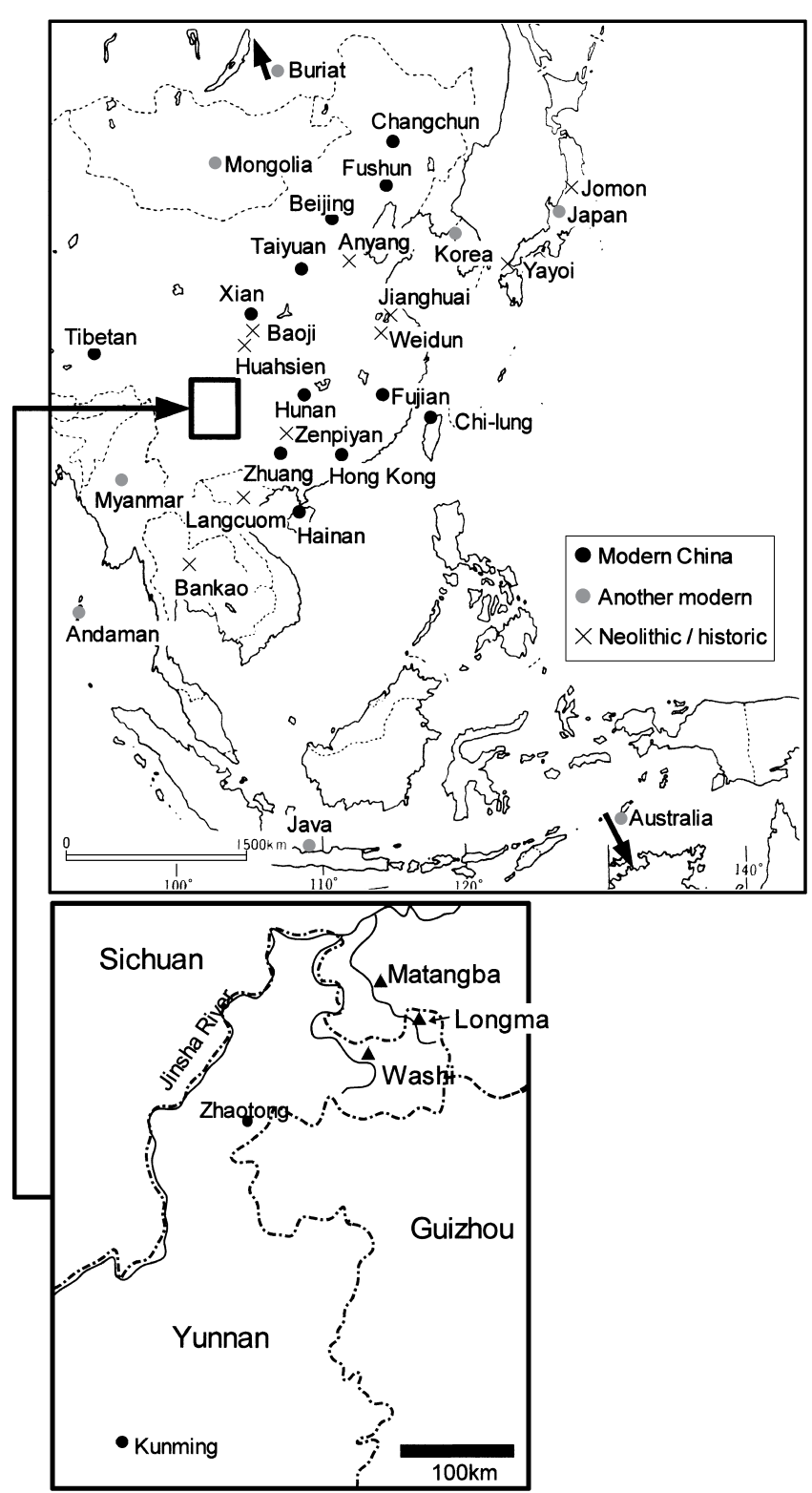

Figure 1. Map of hanging coffin sites near the prefectural border between Yunnan and Sichuan, and the comparative samples around East and Southeast Asia.

\section{Comparative samples}

Comparisons were carried out only with males, since the Washi and Longma skulls were sexed as males. The comparative samples used in the present study range from modern to Neolithic or historic archaeological specimens in and around China, including the previously reported hanging coffin people from Matangba (Hu and Xiao, 1999a), modern Chinese and East/Southeast Asian populations, aboriginal Australian, and Neolithic/historic archaeological samples of the same regions (Table 1, Figure 1). Some of the comparative samples have individual data available that were analyzed to check for extent of individual variation. Other samples, with only the mean data available, were used to represent the population diversity of East/Southeast Asia. 
Table 1. Male cranial series

\begin{tabular}{|c|c|c|c|}
\hline Sample & $\begin{array}{l}\text { No. of } \\
\text { crania }\end{array}$ & Provenance & Source of data \\
\hline \multicolumn{4}{|c|}{ Hanging coffin people } \\
\hline Longma & 1 & NE Yunnan, China & present study \\
\hline Washi & 1 & NE Yunnan, China & present study \\
\hline Matangba & 6 & SE Sichuan, China & $\mathrm{Hu}$ and Xiao (1999a) \\
\hline \multicolumn{4}{|c|}{ Modern Chinese } \\
\hline Changchun & - & NE China & after Liu et al. (1991) \\
\hline Fushun & 77 & NE China & Shima (1933) \\
\hline Beijing & - & NE China & after Liu et al. (1991) \\
\hline Taiyuan & 69 & NE China & Wang and Sun (1988) \\
\hline Xian & - & Central China & after Liu et al. (1991) \\
\hline Fujian & - & SE China & after Liu et al. (1991) \\
\hline Chi-lung & - & Taiwan & after Liu et al. (1991) \\
\hline Hunan & - & SE China & after Liu et al. (1991) \\
\hline Hong Kong & - & SE China & after Liu et al. (1991) \\
\hline Zhuang & - & SE China & after Liu et al. (1991) \\
\hline Hainan & 45 & SE China & Howells (1989) \\
\hline Tibetan & 15 & Tibet & Morant (1923) \\
\hline \multicolumn{4}{|l|}{ Modern Asia } \\
\hline Buriat & 55 & Siberia & Howells (1989) \\
\hline Mongolia & - & Mongol & after Liu et al. (1991) \\
\hline Japan & 53 & Central Japan & Hanihara (2002) \\
\hline Korea & 70 & Kyongsangnam-do & Takenaka (1994) \\
\hline Myanmar & 45 & Southern Myanmar & Tildesley (1921) \\
\hline Andaman & 35 & Andaman Islands & Howells (1989) \\
\hline Java & 30 & Central Java & Bonin (1931) \\
\hline Australia & 52 & $\begin{array}{l}\text { Lower Murray } \\
\text { River }\end{array}$ & Howells (1989) \\
\hline \multicolumn{4}{|c|}{ Neolithic/historic } \\
\hline Jomon & 89 & Neolithic Japan & $\begin{array}{l}\text { Kiyono and Miyamoto } \\
\text { (1926); Kintaka (1928); } \\
\text { Kondo (1993) }\end{array}$ \\
\hline Yayoi & 184 & Aeneolithic Japan & $\begin{array}{l}\text { Nakahashi and Nagai } \\
\text { (1989) }\end{array}$ \\
\hline Anyang & 42 & $\begin{array}{l}\text { Shang Dynasty } \\
\text { China }\end{array}$ & Howells (1989) \\
\hline Jianghuai & 18 & $\begin{array}{l}\text { from East-Zhou to } \\
\text { Early-Han, Jiangnan } \\
\text { region, China }\end{array}$ & Nakahashi and Li (2002) \\
\hline Weidun & 17 & $\begin{array}{l}\text { Neolithic China } \\
\text { Lower Yangtze } \\
\text { River }\end{array}$ & $\begin{array}{l}\text { Yamaguchi and Huang } \\
\text { (1995) }\end{array}$ \\
\hline Baoji & 26 & Neolithic China & after Suzuki (1982) \\
\hline Huahsien & 12 & Neolithic China & after Suzuki (1982) \\
\hline Zhenpiyan & 6 & Neolithic China & after Suzuki (1982) \\
\hline Langcuom & 2 & Neolithic Vietnam & after Suzuki (1982) \\
\hline Bankao & 7 & Neolithic Thailand & after Suzuki (1982) \\
\hline
\end{tabular}

\section{Metric comparisons}

Craniometric comparisons were designed first to evaluate individual variation within the hanging coffin people and make comparisons with variation seen in the comparative samples. Next, we attempted to clarify patterns of populational affinities among the hanging coffin people and comparative samples. Measurements used in the analysis are shown in Table 2. Individual variation was assessed in a metric that represents neurocranial size and in seven shape indices: i.e. cranial modulus $(\mathrm{GOL}+\mathrm{XCB}+\mathrm{BBH}) / 3$ (the threecharacter abbreviations are Howells' definitions, see Table $2)$, length-breadth index (XCB/GOL*100), breadth-height index $\left(\mathrm{BBH} / \mathrm{XCB}^{*} 100\right)$, upper facial index $(\mathrm{NPH} /$ ZYB*100), nasal index (NLB/NLH*100), alveolar prog-
Table 2. Craniometric measurments used in comparisons

\begin{tabular}{|c|c|c|c|c|c|c|}
\hline \multirow[t]{2}{*}{$\begin{array}{l}\text { Martin } \\
\text { No. }\end{array}$} & \multirow{2}{*}{\multicolumn{2}{|c|}{ Howells }} & \multirow[t]{2}{*}{ Index } & \multirow[t]{2}{*}{$\begin{array}{l}\text { Principal } \\
\text { component }\end{array}$} & \multicolumn{2}{|c|}{$\begin{array}{c}\text { Mahalanobis } \\
\text { distance }\end{array}$} \\
\hline & & & & & 1 & 2 \\
\hline M1 & max. cranial length & GOL & $*$ & $*$ & $*$ & $*$ \\
\hline M5 & basion-nasion length & BNL & $*$ & & $*$ & \\
\hline M8 & max. cranial breadth & $\mathrm{XCB}$ & $*$ & $*$ & * & * \\
\hline M17 & $\begin{array}{l}\text { basion-bregma } \\
\text { height }\end{array}$ & $\mathrm{BBH}$ & $*$ & $*$ & $*$ & $*$ \\
\hline M40 & $\begin{array}{l}\text { basion-prosthion } \\
\text { length }\end{array}$ & BPL & $*$ & & $*$ & \\
\hline M45 & bizygomatic breadth & ZYB & $*$ & $*$ & $*$ & * \\
\hline M48 & $\begin{array}{l}\text { upper facial height } \\
\text { (n-pr) }\end{array}$ & NPH & $*$ & $*$ & $*$ & $*$ \\
\hline M48 & $\begin{array}{l}\text { upper facial height } \\
\text { (n-alv) }\end{array}$ & & & & & \\
\hline M51 & $\begin{array}{l}\text { orbital breadth } \\
\text { (mf-ek) }\end{array}$ & & $*$ & $*$ & $*$ & \\
\hline & $\begin{array}{l}\text { orbital breadth } \\
\text { (d-ek) }\end{array}$ & OBB & & & & \\
\hline M52 & orbital height & $\mathrm{OBH}$ & & $*$ & $*$ & $*$ \\
\hline M54 & nasal breadth & NLB & $*$ & $*$ & * & * \\
\hline M55 & nasal height & NLH & $*$ & $*$ & $*$ & * \\
\hline $\begin{array}{r}\text { Facial } \\
\text { simo } \\
\text { simo }\end{array}$ & $\begin{array}{l}\text { flatness } \\
\text { tic chord } \\
\text { tic subtense }\end{array}$ & $\begin{array}{l}\text { WNB } \\
\text { SIS }\end{array}$ & * & & & \\
\hline $\begin{array}{r}\text { Radius } \\
\text { subs } 1 \\
\text { prost }\end{array}$ & $\begin{array}{l}\text { pinale radius } \\
\text { thion radius }\end{array}$ & $\begin{array}{l}\text { SSR } \\
\text { PRR }\end{array}$ & * & & & \\
\hline
\end{tabular}

Mahalanobis distances: 1, within-China comparison; 2, widerranged comparisons.

nathism as expressed by Howells' SSR/PRR (subspinale radius/prosthion radius*100), simotic facial flatness index (SS/SC*100), and gnathic index (BPL/BNL*100). Principal component analysis was applied to the individual data sets, and provided multivariate assessments of variation. In order to establish the biological affiliations of the two hanging coffin skulls, Mahalanobis distances were calculated among the comparative samples. We used 11 measurements in the first analysis, and only included the modern Chinese populations as the comparative sample. In the second analysis, we used 9 measurements to make a broader range of comparison. The measurement items used in each analysis are shown in Table 2 . The variance-covariance matrix used in calculating the Mahalanobis distances was derived from a part of the Howells' dataset. That is, we selected the East and Southeast Asian populations from the Howells' dataset and regarded the calculated variance-covariance matrix as representing the common dispersion structure of this region. The biological distances calculated in the second analysis were visually presented in a two-dimensional plot, using classical multidimensional scaling and the complete linkage method of cluster analysis.

In the multivariate comparison, both size and shape factors of craniometric variation were analyzed together; sizestandardization such as z-scores, C-scores, or standardization by use of the geometric mean, which have been advocated by several researchers (e.g. Howells, 1989; Brace and Tracer, 1992), were not used. This is because size-based variation itself may be an important aspect of populational diversification, and also because it has been suggested that 
the removal of such a size-based component has little or no effect in interpreting patterns of craniometric variation (Pietrusewsky, 1994). In fact, we confirmed little difference in Mahalanobis distances before and after size-adjustment using the geometric mean of variables.

Of the craniometric measurements used in the indices and the multivariate analyses, two measurements, upper facial height and orbital breadth, were inconsistently defined among the comparative samples and thus needed adjustments. Upper facial height was measured by use of different anatomical points, i.e. prosthion (pr) in Howells' method or alveolare (av or sd) in Martin's method. We chose prosthion for our own measurements, and thus recalculated the metrics of those studies that used the alveolar point through a regression equation of two measurements based on a Chinese subsample $\left(n=21, r^{2}=0.967\right)$. In the case of orbital breadth, definitions differed in using either points maxillofrontale (mf) or dakryon (d). We preferred the former, and corrected the metrics of those studies that used dakryon through a regression equation based on a combined Chinese/Japanese sample $\left(n=56, r^{2}=0.738\right)$.

\section{Results}

\section{Description of the skulls}

Both the Washi and Longma skulls are well preserved. Cranial measurements and cranial non-metric trait observations are shown in Appendices 1 and 2. Dental metrics and non-metric characters were not recorded because of bad preservation of the teeth.

The Washi skull (Figure 2a) lacks the mandible and most of the teeth. Only the right upper P2 and the left upper P1, $\mathrm{P} 2$, and M1 survive in the alveolus. Most of the enamel of the crown is cracked off but the occlusal surface of the left P1 to M1 is presumably flat with a moderate degree of wear: grade 2 according to the Molnar (1971) scale. The neurocranium is ovoid in superior view, and relatively high and wide. The length-breadth index (79.95) falls into the upper limit of the range of 'mesocrany'. The face is low and relatively wide. The orbita is rectangular in shape and its long axis is inferolaterally inclined. The nasal bone is narrow but protrudes anteriorly from nasal root to rhinion and its horizontal curvature is strong. The canine fossa is shallow.

The Longma skull (Figure 2b) has both cranium with left $\mathrm{P} 1$ and $\mathrm{P} 2$ and mandible with right P2 and left I1, C, P1, P2, and M2. The enamel of the crown is mostly chipped off. The upper P1 and P2 suffer from severe caries with an abscess at the buccal alveolus of $\mathrm{P} 1$ and a large interproximal cavity at the mesial wall of P2. Occlusal wear is advanced: grade 3 in the upper right $\mathrm{P} 2$, grade 2 in the lower right $\mathrm{P} 2$, and grade 4 in the lower left P2 and M2, according to the Molnar (1971) scale. Antemortem tooth loss was detected at the position of upper right M2 and lower left M1, where the alveolar socket was completely absorbed. The skull is missing only its right zygomatic portion. The neurocranium is ovoid (mesocrany according to a length-breadth index of 76.2) and relatively high. The face is low and wide, possessing a wide nasal aperture and a deep canine fossa. The zygomatic bone is large and faces anteriorly. The nasal bone is wide but its anterior protrusion is weak and horizontally flat, in contrast to the strong nasal root profile of the Washi skull. The orbita is horizontally directed and rectangular in shape. The anterior alveolar bone of the maxilla shows strong alveolar prognathism.

Both Washi and Longma skulls are presumably adult males based on the cranial superstructures. They share such masculine features as a developed superior nuchal line, a thick and round supraorbital margin, and a wide and laterally developed zygomatic process of the frontal bone. There is a difference in dimension of the mastoid process, however. The mastoid process of the Washi skull is massive, while that of the Longma is small. The Longma mastoid process, however, points downwards, unlike female mastoid processes which point inferomedially. Based on the degree of ectocranial suture closure, although obliteration stages of the respective regions were different, both skulls were evaluated as being in the same category of composite scores, indicating a middle-aged adult, presumably $30-50$ years old.

\section{Assessment of individual variation}

The cranial modulus and seven indices of the two skulls fall within the range of variation of the comparative samples from Buriat at the northern to Australia at the southern end of the comparative range (Figure 3 ). There is little difference between the Washi and Longma crania, indicating the generally similar shape of the two specimens. The similarity includes a relatively narrow cranium and a low and orthognathous face. One exceptional difference between the Washi and Longma crania is in the simotic index, the former with a protruding and latter with a flat nasal root.

Principal component analysis gives us a multivariate expression of skull shape. We first looked at nine variables, and assessed individual variation between the two Yunnan skulls in relation to that seen among the respective populations (Table 3, Figure 4). Scatter plots of individual scores up to the 4 th principal component, which express $91 \%$ of the total variation, indicate that the two Yunnan skulls fall close to each other. Viewing the hanging coffin people in total, the two skulls of the present study and those of Matangba can be regarded as representing a single population, because they make a tight cluster. Their locations in multivariate space approximate the average positions of the Jomon and Anyang series. Judging from the factor loadings, the 1st component expresses the dimension of the neurocranium and the face, placing Buriat at the largest and Andaman at the smallest end. The 2nd component expresses the cranial index, i.e. dolicho- or brachycephaly, and puts the aboriginal Australians at the extreme dolichocephalic position. The 3rd and 4th components indicate cranial height and facial breadthheight proportions, respectively, indicating that the hanging coffin people have a relatively high vault and a low face.

\section{Populational affinity}

Mahalanobis distances between the Washi and Longma crania, and the modern Chinese indicate that the two Yunnan skulls are most similar to the Zhuang modern Chinese residents of Guangxi province (Figure 5). This is consistent with previous analyses conducted on the Matangba hanging coffin people (Hu and Xiao, 1999a). It should be noted that the inter-individual distance between Washi and Longma, repre- 

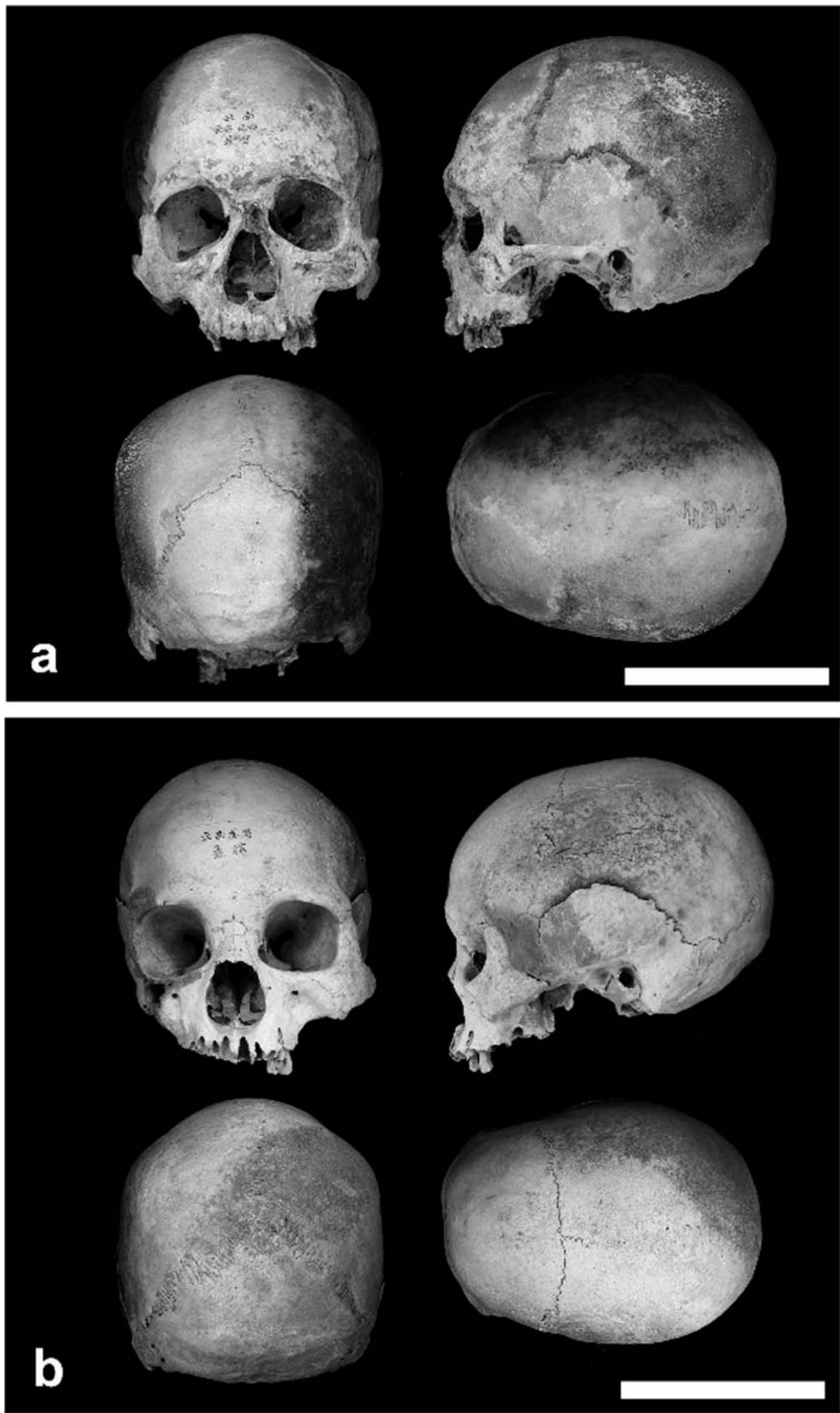

Figure 2. Skulls of Yunnan Tang dynasty hanging coffin people from the sites of Washi (a) and Longma (b). Scale bar equals $10 \mathrm{~cm}$. 

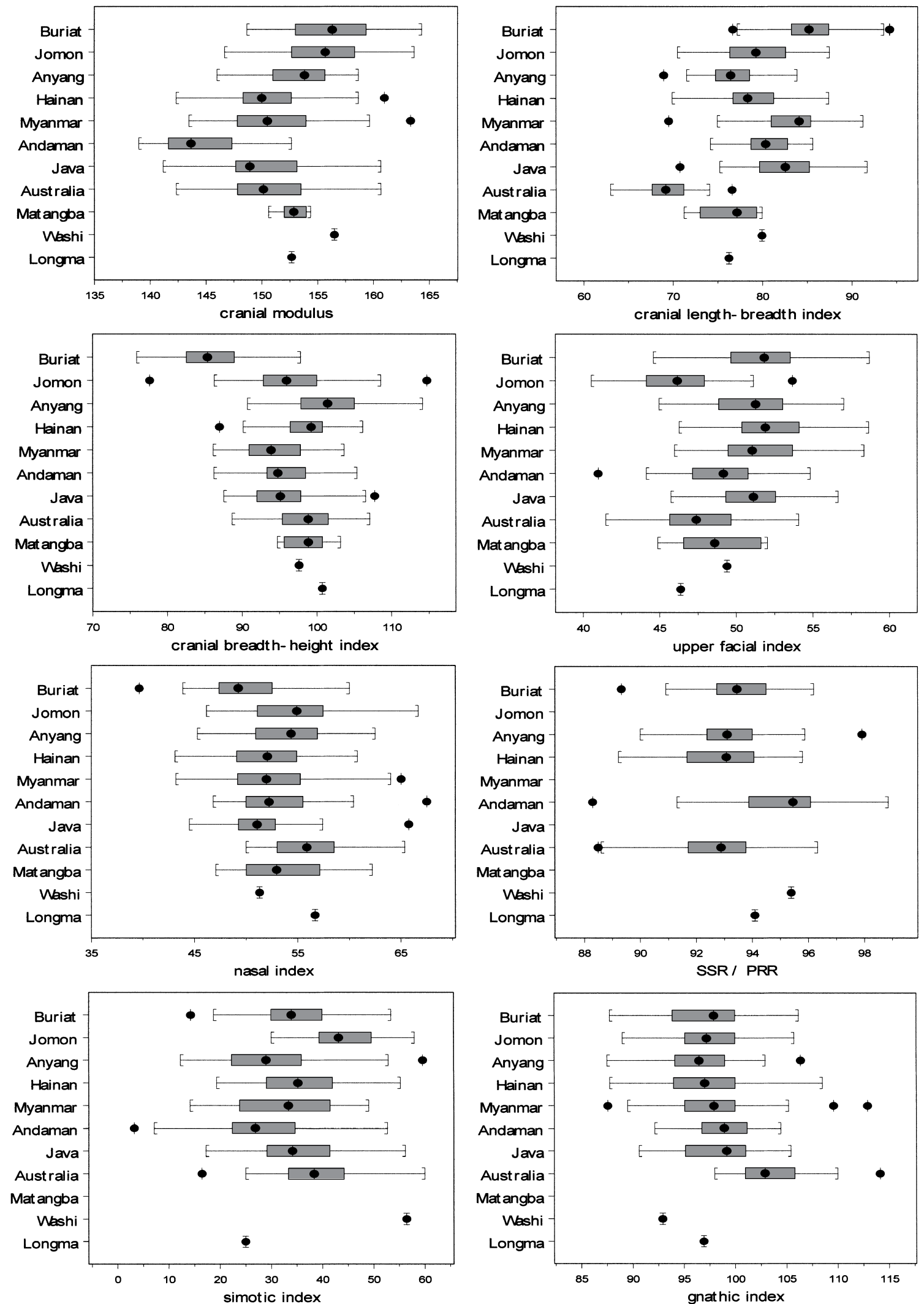

Figure 3. Box plots of eight cranial and facial indices of the comparative samples. The box indicates the lower to upper quartiles and the dot indicates the median. 

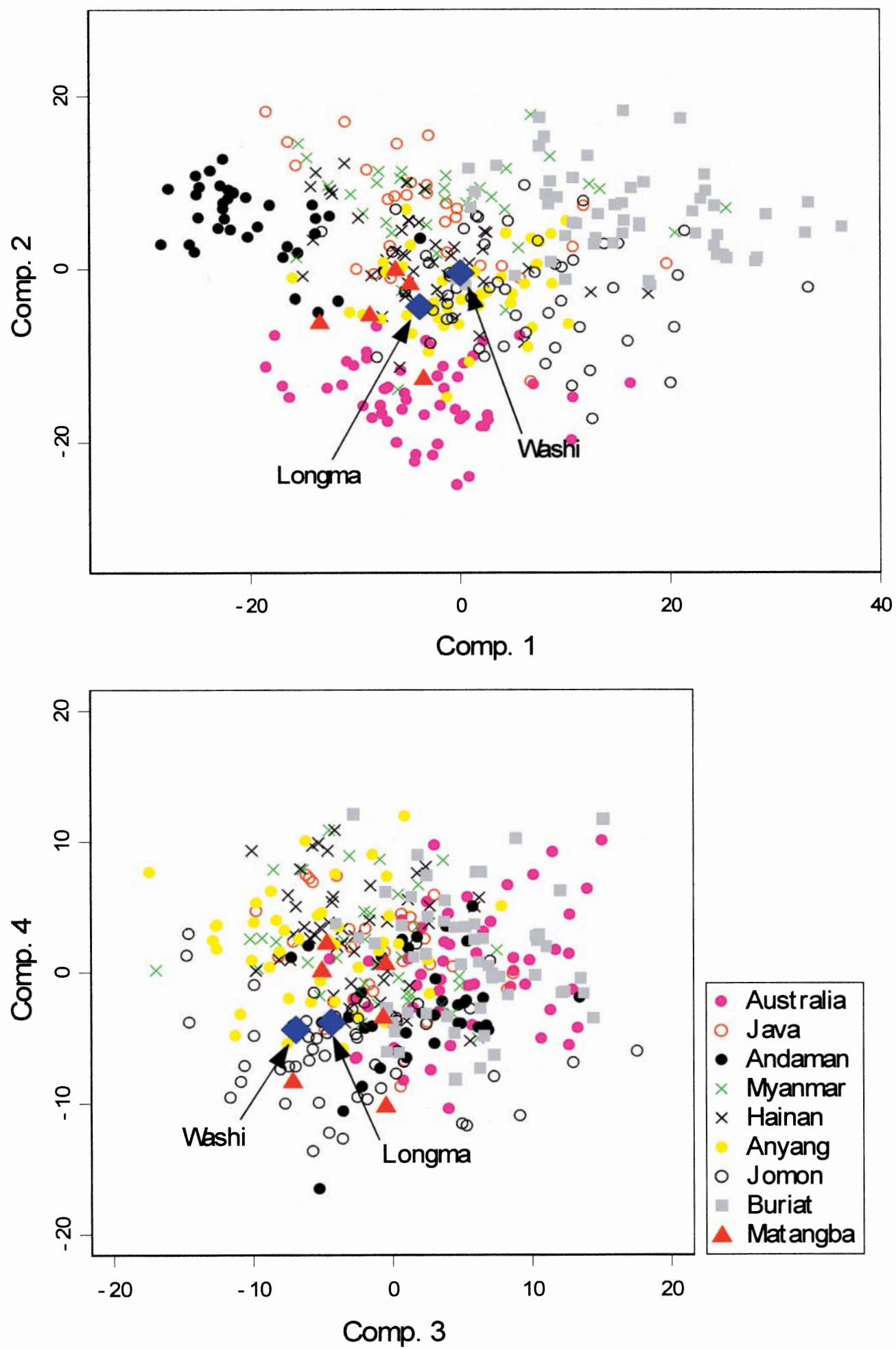

Figure 4. Two-dimensional plots of the first to fourth principal component scores of the comparative samples with individual data.

sented by the dotted line in Figure 5 , is greater than that between the Zhuang and each of them. Furthermore, judging from the distance-order presented in Figure 5, we can assume that populational affinities between the Yunnan skulls and the modern Chinese correspond roughly to geo- graphical distance; the southeastern modern populations consistently have a smaller distance from the two Yunnan skulls.

The second comparison puts the hanging coffin people in a broader regional and/or temporal perspective. Here, the 
Table 3. Principal component analysis

\begin{tabular}{|c|c|c|c|c|c|c|c|c|}
\hline & Comp. 1 & Comp. 2 & Comp. 3 & Comp. 4 & Comp. 5 & Comp. 6 & Comp. 7 & Comp. 8 \\
\hline GOL & 0.387 & -0.820 & 0.107 & & -0.401 & & & \\
\hline $\mathrm{XCB}$ & 0.574 & 0.530 & 0.111 & -0.382 & -0.477 & & & \\
\hline BBH & 0.196 & & -0.975 & & & & & \\
\hline ZYB & 0.562 & & 0.129 & -0.198 & 0.771 & & & -0.106 \\
\hline NPH & 0.311 & 0.141 & & 0.739 & & -0.256 & 0.338 & 0.376 \\
\hline Orbital breadth & & & & & 0.107 & -0.186 & -0.507 & 0.514 \\
\hline OBH & & & & 0.147 & & -0.166 & -0.741 & \\
\hline NLB & & & & & & 0.888 & & 0.408 \\
\hline NLH & 0.222 & 0.106 & & 0.486 & & 0.280 & -0.246 & -0.643 \\
\hline Cumulative proportion & 0.456 & 0.703 & 0.830 & 0.913 & 0.964 & 0.975 & 0.986 & 0.994 \\
\hline
\end{tabular}

Factor loadings with absolute values $>0.1$ are presented.
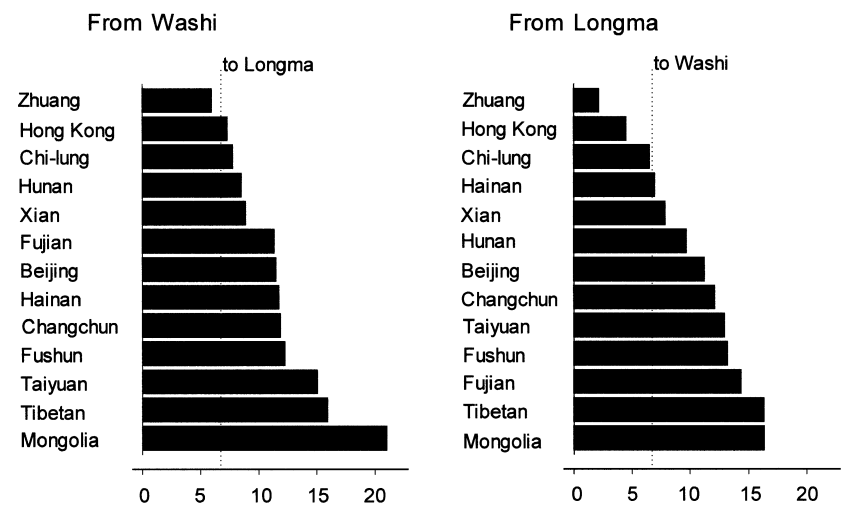

Figure 5. Mahalanobis distances from Washi (left) and Longma (right) to the modern Chinese samples. Eleven variables were included. The inter-individual distance between Washi and Longma is shown as the dotted line.

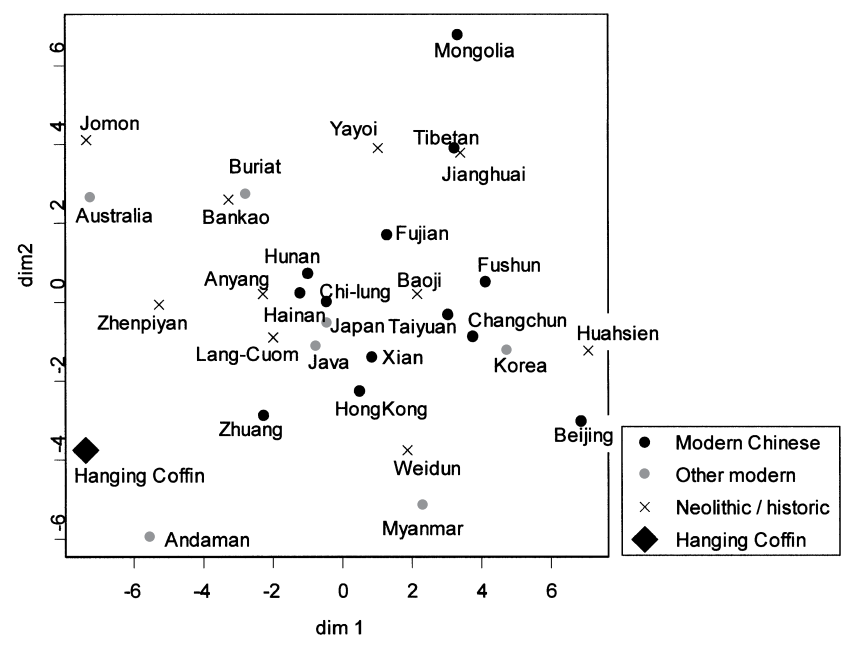

Figure 6. Multidimensional scaling plot of Mahalanobis distances based on nine variables (Table 4), using a wider range of comparative samples.

Washi, Longma, and Matangba skulls were combined into one sample because the degree of individual variation within this combined group was comparable with those of other modern samples. Mahalanobis distances were calculated and are shown in Table 4. A two-dimensional representation of the distance matrix, using multi-dimensional scaling (MDS), is given in Figure 6 (the first two axes account for $72 \%$ of the total variation). The results show that the position of the hanging coffin people in multivariate space is peripheral among the comparative samples and beyond the range of variation of the modern Chinese means. Of all the amonggroup distances, the smallest from the hanging coffin group was that to the Zhenpiyan (3.287), a Neolithic sample from southeast China, and the second smallest distance was to the Anyang (Shang dynasty) Chinese. These results are plausible from a geographical and historical point of view, although the distances themselves were not small enough to suggest a particularly tight affinity.

In Figure 6, the group closest to the hanging coffin people is the Andaman islanders. This graphical configuration may include some degree of distortion of the underlying statistical and biological relationships. We believe this to be the case because the distance from the hanging coffin people to Andaman group itself is not particularly small, but almost equivalent to those from the hanging coffin group to some of the mainland Asian samples. Such an interpretation is consistent with the clustering pattern shown in Figure 7. The hanging coffin people group first unites with Zhenpiyan and then makes a cluster with Australia/Jomon and Andaman, and not with the other mainland population groups. The cluster of the hanging coffin people to Zhenpiyan is conceivable in terms of regional and temporal variation. However, the relatively small distance to the Australia/Jomon groups may not represent biological relationships. The apparent proximity between Australia and the hanging coffin group in the cluster analysis is not supported by a direct comparison of the original distances (Table 4); the distance between the two is not small, and is near the median (13/30) of distances between the hanging coffin and comparative samples. The position of the Jomon sample is variable, depending on the choice of clustering method. If we use the group-average method, Jomon joins with Buriat, far from Australia and the hanging coffin-Zhenpiyan cluster. It is plausible that these peripheral populations are loosely joined together outside of the tighter connection seen with the other mainland Asian populations.

These results lead to the assessment that the hanging coffin people are largely unique, i.e. distant from modern populations of mainland China and closer to the Neolithic 
Table 4. Mahalanobis distances among hanging coffin people and comparative samples

\begin{tabular}{|c|c|c|c|c|c|c|c|c|c|c|c|c|c|c|c|}
\hline & $\begin{array}{c}\text { Hanging } \\
\text { Coffin }\end{array}$ & $\begin{array}{l}\text { Chang- } \\
\text { chun }\end{array}$ & Fushun & Beijing & Taiyuan & $\begin{array}{l}\text { Mon- } \\
\text { golia }\end{array}$ & Xian & Tibetan & Hunan & Fujian & $\begin{array}{l}\text { Chi- } \\
\text { lung }\end{array}$ & Zhuang & $\begin{array}{c}\text { Hong- } \\
\text { Kong }\end{array}$ & Hainan & Japan \\
\hline Changchun & 10.945 & & & & & & & & & & & & & & \\
\hline Fushun & 10.928 & 1.057 & & & & & & & & & & & & & \\
\hline Beijing & 14.340 & 2.846 & 3.016 & & & & & & & & & & & & \\
\hline Taiyuan & 10.634 & 1.194 & 1.173 & 3.531 & & & & & & & & & & & \\
\hline Mongolia & 15.898 & 5.480 & 4.494 & 8.483 & 4.653 & & & & & & & & & & \\
\hline Xian & 6.975 & 1.817 & 1.869 & 3.492 & 1.467 & 5.845 & & & & & & & & & \\
\hline Tibetan & 13.220 & 2.101 & 2.157 & 6.531 & 3.201 & 2.703 & 3.531 & & & & & & & & \\
\hline Hunan & 4.742 & 2.878 & 2.700 & 6.641 & 2.353 & 4.383 & 1.785 & 3.672 & & & & & & & \\
\hline Fujian & 7.902 & 2.410 & 1.817 & 7.516 & 2.598 & 6.350 & 3.923 & 3.100 & 2.161 & & & & & & \\
\hline Chi-lung & 4.931 & 2.192 & 1.960 & 4.848 & 1.835 & 4.534 & 1.214 & 3.2 & & & & & & & \\
\hline Zhuang & 5.012 & 6.853 & 7.305 & 5.825 & 6.171 & 9.408 & 3.469 & 10.017 & 4.315 & 9.010 & 2.921 & & & & \\
\hline Hong Kong & 5.657 & 4.183 & 3.283 & 3.063 & 4.006 & 8.021 & 2.192 & 7.429 & 2.993 & & 1.876 & 1.821 & & & \\
\hline Hainan & 4.591 & 4.731 & 4.429 & 9.168 & 4.189 & 5.613 & 3.324 & 5.819 & 1.192 & 3.639 & 1.301 & 4.403 & 3.338 & & \\
\hline Japan & 4.610 & 2.242 & 2.084 & 3.525 & 2.025 & 5.625 & 1.044 & 4.114 & 1.240 & 2.703 & 0.347 & 2.007 & 1.100 & & \\
\hline Korea & 12.089 & 4.470 & 3.584 & 3.493 & 4.590 & 7.301 & 4.381 & 8.223 & 5.491 & 6.888 & 3.849 & 4.355 & 2.113 & 5.272 & 3.277 \\
\hline Buriat & 9.840 & 8.580 & 9.922 & 12.641 & 9.550 & 7.521 & 7.429 & 8.832 & 4.514 & 9.369 & 6.893 & 6.958 & 8.645 & & 6.370 \\
\hline Myanmar & 11.194 & 5.848 & 8.191 & 4.896 & 8.135 & 11.266 & 5.442 & 10.640 & 7.235 & 11.659 & 5.873 & 3.398 & 3.740 & & 4.954 \\
\hline Andaman & 4.602 & 8.917 & 12.096 & 12.413 & 8.808 & 16.015 & 7.923 & 13.714 & 6.185 & 9.294 & 5.874 & 5.589 & 7.748 & 6.029 & 5.735 \\
\hline Java & 6.084 & 4.805 & 5.753 & 6.763 & 4.591 & 6.486 & 3.614 & 7.879 & 2.449 & 6.306 & 2.154 & 1.864 & 2.544 & & 2.205 \\
\hline Australia & 7.705 & 12.240 & 12.406 & 14.318 & 11.846 & 9.079 & 8.318 & 9.018 & 7.256 & 12.140 & 6.307 & 6.900 & 9.342 & 7.770 & 6.891 \\
\hline Jomon & 6.423 & 13.281 & 12.784 & 16.781 & 12.726 & 10.597 & 11.558 & 12.293 & 7.240 & 9.135 & 6.374 & 6.831 & 9.362 & 6.775 & 6.560 \\
\hline Yayoi & 10.296 & 4.560 & 3.549 & 7.741 & 5.281 & 2.836 & 5.962 & 3.144 & 3.600 & 3.087 & 2.657 & 7.443 & 5.434 & 3.937 & 3.356 \\
\hline Anyang & 3.810 & 8.050 & 6.528 & 11.722 & 7.582 & 8.154 & 5.075 & 8.573 & 2.762 & 5.905 & 2.810 & 5.079 & 3.612 & 0.944 & 3.695 \\
\hline Jianghuai & 13.346 & 4.514 & 4.143 & 9.850 & 5.513 & 3.341 & 6.699 & 3.733 & 4.592 & 4.082 & 3.690 & 9.958 & 7.303 & 3.275 & 5.403 \\
\hline Weidun & 8.313 & 5.484 & 5.432 & 4.509 & 7.085 & 10.412 & 4.540 & 9.497 & 5.756 & 8.300 & 3.859 & 3.269 & 1.331 & 4.584 & 3.300 \\
\hline Baoji & 9.662 & 4.693 & 4.064 & 5.335 & 6.556 & 7.264 & 5.971 & 6.490 & 5.380 & 5.053 & 3.251 & 5.465 & 2.965 & 4.715 & 3.137 \\
\hline Huahsien & 13.831 & 6.653 & 5.341 & 7.569 & 9.381 & 10.557 & 8.652 & 9.003 & 8.171 & 7.401 & 6.488 & 10.641 & 5.023 & 6.594 & 6.843 \\
\hline Zhenpiyan & 3.287 & 10.292 & 9.251 & 14.328 & 11.254 & 13.750 & 6.035 & 9.357 & 5.340 & 7.894 & 5.771 & 7.948 & 7.141 & 6.576 & 5.558 \\
\hline Lang-Cuom & 9.153 & 9.929 & 10.613 & 15.692 & 10.494 & 10.607 & 7.671 & 10.168 & 7.371 & 10.527 & 5.348 & 7.703 & 8.507 & 3.442 & 7.399 \\
\hline Bankao & 10.104 & 12.903 & 12.276 & 13.446 & 12.491 & 9.092 & 11.816 & 13.864 & 6.615 & 11.294 & 8.401 & 7.027 & 7.785 & 7.598 & 7.511 \\
\hline
\end{tabular}

population of Zhenpiyan. The relatively isolated position of the hanging coffin people is similar to the situation seen in the Jomon, aboriginal Australian, and Andaman islander samples in contrast to the other mainland East/Southeast Asian populations.

\section{Discussion}

The present study describes two newly uncovered skulls of the hanging coffin people of Yunnan Province, and provides a new basis of discussion for the biological affiliation of the hanging coffin people and the population history of East/Southeast Asia.

As for the biological affiliation of the hanging coffin people, we confirmed the close affinity with the modern Zhuang people of Southeast China in the limited comparison with modern Chinese groups. This result was consistent with a previous craniometric analysis of Matangba samples $(\mathrm{Hu}$ and Xiao, 1999a). However, analysis reported in the current paper, which is based on broader comparative samples, indicated that the position of the hanging coffin people was not central but peripheral to the modern population stocks of East/Southeast Asia. This leads us to a conclusion that the biological identity of the hanging coffin people is unique, and that such a situation is similar to that of the Jomon, aboriginal Australians, and Andaman islanders.

We should note that this does not indicate that the hanging coffin people was an out-group to the comparative modern
Asian populations. From individual scatterplots along the first few principal components (Figure 4), all the hanging coffin specimens are well within the ranges of variation and even relatively central in the 1 st and 2 nd component plots. In addition, close inspection of Mahalanobis distances of each population from the hanging coffin people exhibits some degree of geographical and temporal association-for example, a closer position of the Zhuang people of modern Chinese and Zhenpiyan of Neolithic Chinese.

Thus, it is worth considering the relationship of the hanging coffin people to the modern Zhuang or to the Neolithic Zhenpiyan. Interestingly, the Zhuang people and the Zhenpiyan Neolithic people have been mentioned as closely related, possibly ancestral-descendant populations (Barlow, 1987). Most authorities agree that the ancestral peoples of the Zhuang, the largest minority ethnic group in China, were Thai-related peoples who probably emigrated from the south in Vietnam. One of the archaeological sites supporting this scenario is Zhenpiyan, Guangxi province, dated ca. $10000 \mathrm{BP}$, where associated burials were common not to China but to the Hoabinhian (9000-5600 BC) and Bacsonian (8300-5900 BC) cultures of Vietnam (Barlow, 1987).

What does the observed peculiarity of the hanging coffin people suggest for the population history of China, or of East/Southeast Asia? We should take into account both geographical and chronological settings. The Yunnan hanging coffin people are conceivably accepted as a representative of local, relatively mountainous inhabitants at the age of the 
Table 4. (continued)

\begin{tabular}{|c|c|c|c|c|c|c|c|c|c|c|c|c|c|c|c|}
\hline & Korea & Buriat & $\begin{array}{c}\text { Myan- } \\
\text { mar }\end{array}$ & $\begin{array}{c}\text { Anda- } \\
\text { man }\end{array}$ & Java & $\begin{array}{c}\text { Aust- } \\
\text { ralia }\end{array}$ & Jomon & Yayoi & Anyang & $\begin{array}{c}\text { Jiang- } \\
\text { huai }\end{array}$ & Weidun & Baoji & $\begin{array}{c}\text { Huah- } \\
\text { sien }\end{array}$ & $\begin{array}{l}\text { Zhen- } \\
\text { piyan }\end{array}$ & $\begin{array}{l}\text { Lang- } \\
\text { Cuom }\end{array}$ \\
\hline \multicolumn{16}{|l|}{ Changchun } \\
\hline \multicolumn{16}{|l|}{ Fushun } \\
\hline \multicolumn{16}{|l|}{ Beijing } \\
\hline \multicolumn{16}{|l|}{ Taiyuan } \\
\hline \multicolumn{16}{|l|}{ Mongolia } \\
\hline \multicolumn{16}{|l|}{ Xian } \\
\hline \multicolumn{16}{|l|}{ Tibetan } \\
\hline \multicolumn{16}{|l|}{ Hunan } \\
\hline \multicolumn{16}{|l|}{ Fujian } \\
\hline \multicolumn{16}{|l|}{ Chi-lung } \\
\hline \multicolumn{16}{|l|}{ Zhuang } \\
\hline \multicolumn{16}{|l|}{ Hong Kong } \\
\hline \multirow{2}{*}{\multicolumn{16}{|c|}{$\begin{array}{l}\text { Hainan } \\
\text { Japan }\end{array}$}} \\
\hline & & & & & & & & & & & & & & & \\
\hline \multicolumn{16}{|l|}{ Korea } \\
\hline Buriat & 9.114 & & & & & & & & & & & & & & \\
\hline Myanmar & 3.944 & 8.202 & & & & & & & & & & & & & \\
\hline Andaman & 12.766 & 11.668 & 8.555 & & & & & & & & & & & & \\
\hline Java & 3.204 & 4.767 & 2.938 & 4.859 & & & & & & & & & & & \\
\hline Australia & 15.900 & 11.483 & 13.064 & 10.083 & 9.041 & & & & & & & & & & \\
\hline Jomon & 11.650 & 7.904 & 14.038 & 9.894 & 6.764 & 7.506 & & & & & & & & & \\
\hline Yayoi & 5.273 & 7.402 & 9.525 & 12.152 & 5.085 & 8.570 & 5.125 & & & & & & & & \\
\hline Anyang & 6.504 & 8.077 & 8.580 & 8.869 & 3.327 & 7.941 & 6.949 & 5.345 & & & & & & & \\
\hline Jianghuai & 5.473 & 9.133 & 9.398 & 13.453 & 5.039 & 12.503 & 9.500 & 1.775 & 5.357 & & & & & & \\
\hline Weidun & 1.993 & 10.126 & 1.924 & 9.663 & 3.011 & 12.375 & 11.638 & 6.661 & 4.612 & 6.927 & & & & & \\
\hline Baoji & 2.327 & 9.416 & 5.199 & 11.375 & 4.138 & 11.903 & 7.387 & 2.142 & 5.321 & 3.506 & 2.178 & & & & \\
\hline Huahsien & 4.280 & 14.832 & 7.458 & 16.393 & 7.588 & 17.739 & 15.308 & 5.574 & 6.523 & 4.764 & 2.955 & 2.123 & & & \\
\hline Zhenpiyan & 13.100 & 8.997 & 13.188 & 12.129 & 9.614 & 7.556 & 9.508 & 9.687 & 4.871 & 12.866 & 9.709 & 10.304 & 13.503 & & \\
\hline Lang-Cuom & 9.677 & 12.108 & 8.795 & 10.466 & 5.129 & 9.698 & 10.727 & 8.680 & 3.847 & 5.679 & 7.031 & 8.259 & 10.123 & 10.117 & \\
\hline Bankao & 8.834 & 4.542 & 10.553 & 12.287 & 5.403 & 12.103 & 5.145 & 6.591 & 7.997 & 10.622 & 9.855 & 7.770 & 13.130 & 13.492 & 16.157 \\
\hline
\end{tabular}

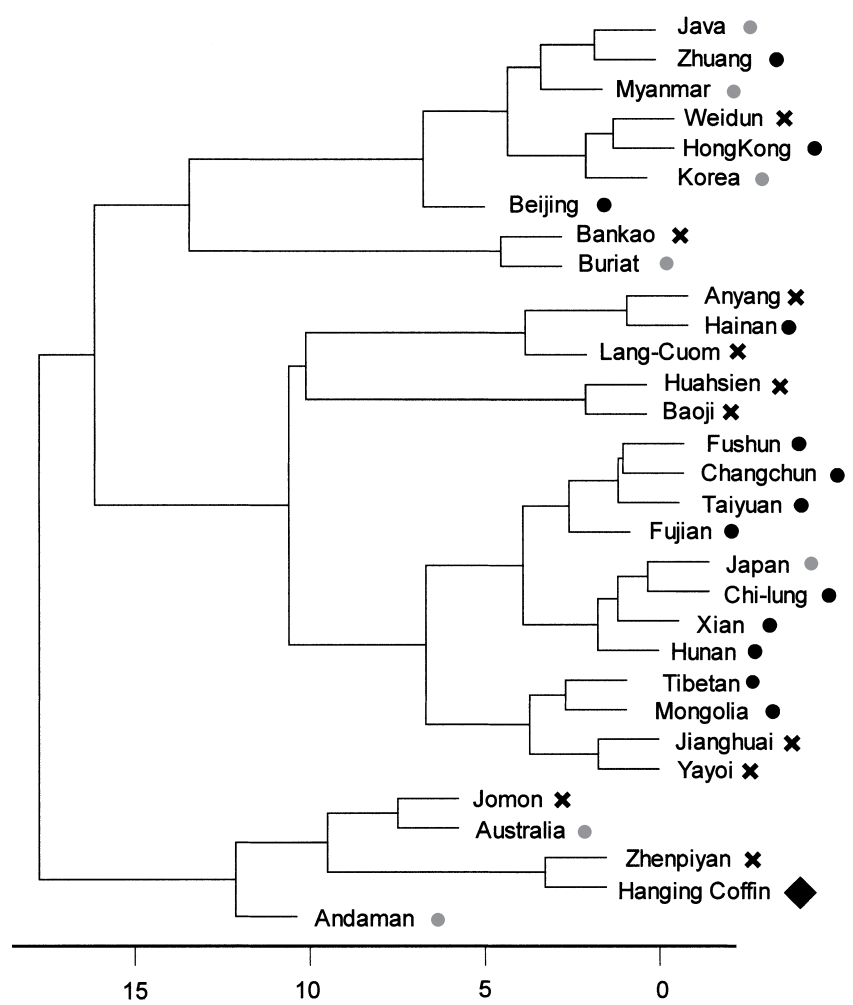

Figure 7. Results of complete-linkage method of cluster analysis based on the Mahalanobis distance matrix of Table 4.
Tang dynasty, ancient China, around one millennium before the present.

Concerning the population history of East/Southeast Asia, previous analyses have suggested a systematic regional difference between the northern and southern groups based on skeletal (dental and cranial) (Turner, 1987; Pietrusewsky et al., 1992; Hahihara, 1994; Pietrusewsky, 1994), linguistic (Ruhlen, 1994), and genetic evidence (Cavalli-Sforza et al., 1994 for a review), although a recent publication using genetic and virus markers has questioned this (Ding et al., 2000). A general dichotomous pattern of population diversity has been also observed among modern Chinese (Wang, 1986; Liu et al., 1991) and it might be traced back to the Neolithic period (Wang, 1986). Due to a poor density of information in terms of both temporal and geographical variation, however, the extent of regional continuity or patterns of chronological fluctuation in the boundary between the two hypothetical population stocks have not yet been clarified with reasonable resolution. With the evidence from Southeast Asia, Pietrusewsky (1994) pointed out that the Bronze age Thai series connected with the southern stock of Australo-Melanesian groups, while Matsumura et al. (2001) argued that the dental characteristics of northern Vietnam populations shifted from the southern type (Sundadont) in Hoabinian-Neolithic times to northern type (Sinodont) in early Metal age or later.

From the results of the present study, we detected a degree of regional affinity among comparative samples although 
the north-south dichotomy was not clear. Among these samples, the relatively isolated position of the hanging coffin people is striking, well distant from Myanmar and Java of modern times and rather close to Zhenpiyan of the Neolithic. What does this mean? It could be postulated that the hanging coffin people was a quite localized, isolated minority and thus its biological peculiarities were accentuated in cranial morphology. They could have derived from the southern stock in the East/Southeast Asian population history, which presumably includes the Neolithic Zhenpiyan and Hoabinian of Vietnam. During long temporal and geographical isolation, the peculiarities of the hanging coffin people may have accumulated in the mountainous region. In the continental plains, on the other hand, the northern and the southern population stocks might have resulted in admixture, and this could have had the effect of emphasizing the peculiarity of the hanging coffin people. Considering the presence of a number of local minorities now living in Yunnan province, this scenario is plausible.

In the context of Japanese population history, interest focuses on the biological position of the Jomon and Yayoi, and identifying populations that are closer to them among the comparative samples. This is because, in Japanese population history, the two groups have been widely accepted as the main constituent populational stocks. Thus, the origins or pathways of the two ancient groups have long been discussed. Recently, some have tried to identify the plausible continental ancestors of the immigrant Yayoi people, in and around the mainland of China (Kim et al., 1993; Yamaguchi and Huang, 1995; Han and Matsushita, 1997; Nakahashi and $\mathrm{Li}, 2002)$.

In the present study, we did not find any close relationships between the hanging coffin people and the Jomon or Yayoi. As the hanging coffin people occupied a peripheral, isolated position in our analysis, no meaningful inference was drawn on the origin of the Jomon or Yayoi. However, we could at least deduce that the hanging coffin people, or its ancestral group, is unlikely to have contributed to the origin of the Yayoi people. The close position of the Jianghuai (East-Zhou to Early-Han people in Jiangnan region) to the Yayoi people confirms the results of a recent report (Nakahashi and $\mathrm{Li}, 2002$ ) which suggested that one promising region for the origin of the Yayoi people is around the lower reaches of the Yangtze river.

Concerning comparisons with the Jomon people, the relatively low and wide face of the hanging coffin people is shared with the Jomon, as well as with the aboriginal Australians. In addition, the protruding nasal bone of one of the Yunnan skulls, Washi, is also suggestive of a similarity with the Jomon. However, these similarities were not sufficient to result in distance analyses that suggested close affinities of the hanging coffin and Jomon people. Concerning the low and wide face, the range of variation of the hanging coffin people overlapped extensively with those of the other comparative samples. On the other hand, the nasal configuration of the two Yunnan skulls exhibited a high degree of contrast, a protruding nasal root in Washi but flat in Longma. Furthermore, the protruding nasal bone of the Washi itself was not identical to the Jomon condition. The latter is characterized by a wide and sagittally oriented bony strut at the medial wall of the orbit, involving the frontal process of the maxilla (Suzuki, 1969), while the frontal process of the maxilla of the Washi faced anteriorly.

\section{Conclusions}

The two crania of the Yunnan hanging coffin people provide evidence for the following interpretations concerning the biological affinities of the hanging coffin people and the population history of China and the surrounding area.

1. The cranial morphology of the hanging coffin people falls well within the general range of variation among East/Southeast Asian people, including aboriginal Australians and Andaman islanders.

2. The hanging coffin people are a unique, relatively peripheral population in terms of their biological affinities among East/Southeast Asian population stocks. They show weak affinities with mainland Chinese populations.

3. The degree of regional and chronological affinities detected among the hanging coffin people and the mainland Chinese populations may be suggestive of ancient population dynamics (gene flow). However, the isolated morphological position of the hanging coffin people may have resulted from population isolation.

\section{Acknowledgments}

We would like to thank Mr Yu Tengsong and Lin Qingming of the Cultural Relics Administration Office of Weixin, and Ms Ding Changfen of the Cultural Relics Administration Office for their cooperation during field investigation. We also thank the Zhaotong and Weixin governments and the Kumning Institute of Zoology, Chinese Academy of Sciences for offering facilities during the visit to Yunnan by two of us (M.N. and O.K.). Thanks to Mr Li Weiqing for his useful suggestions. The field investigation was financially supported by Bang Production Ltd, Hong Kong. This research was supported by a grant from the Matsushita International Foundation.

\section{References}

Barlow J.G. (1987) The Zhuang minority of the Sino-Vietnamese frontier in the Song Period. Journal of Southeast Asian Studies, 18: 250-269.

Bonin G. (1931) Beitrag zur Kraniologie von Ost-Asien. Biometrika, 23: 52-113.

Brace C.L. and Tracer D.P. (1992) Craniofacial continuity and change: a comparison of late Pleistocene and recent Europe and Asia. In: Akazawa T., Aoki K., and Kimura T. (eds.), The Evolution and Dispersal of Modern Humans in Asia. Hokusen-sha, Tokyo, pp. 439-471.

Bräuer G. (1988) Osteometrie. In: Martin R. and Knußmann K. (eds.), Anthropologie, Handbuch der vergleichenden Biologie des Menschen, Band 1. Gustav Fischer, Stuttgart, pp. 160 232.

Buikstra J.E. and Ubelaker D.H. (1994) Standards for data collection from human skeletal remains. Arkansas Archaeological Survey Research Series, No. 44. Arkansas Archaeological Survey, Fayetteville, Arkansas.

Cavalli-Sforza L.L., Menozzi P., and Piazza A. (1994) The History 
and Geography of Human Genes. Princeton University Press, Princeton.

Ding Y.C., Wooding S., Harpending H.C., Chi H.C, Li H.P., Fu Y.X., Pang J.F., Yao Y.G., Xiang Yu J.G., Moyzis R., and Zhang Y.P. (2000) Population structure and history in East Asia. Proceedings of National Academy of Science of the United States of America, 97: 14003-14006.

Han K. and Matsushita T. (1997) A summary report on studies into the physical characteristics of Zhou-Han human skeletons from Linzi, Shandong, and their comparison with Yayoi skeletons from western Japan. Kaogu, 4: 32-45.

Hanihara K. (2002) Metric data for the Modern and Edo era Japanese crania. The University Museum, The University of Tokyo, Material Reports, No. 47, The University Museum, The University of Tokyo.

Hanihara T. (1994) Craniofacial continuity and discontinuity of Far Easterners in the Late Pleistocene and Holocene. Journal of Human Evolution, 27: 417-441.

Howells W.W. (1973) Cranial variation in man. Papers of the Peabody Museum of Archaeology and Ethnology, Volume 67. Harvard University Press, Cambridge.

Howells W.W. (1989) Skull shapes and the map. Papers of the Peabody Museum of Archaeology and Ethnology, Volume 79. Harvard University Press, Cambridge.

Hu X. and Xiao H. (1999a) A metrical study on Bo Ren skulls. Chinese Journal of Anatomy, 22: 357-361 (in Chinese).

$\mathrm{Hu}$ X. and Xiao H. (1999b) Nonmetrical research of crania in "Bo Ren". Chinese Journal of Anatomy, 22: 261-264 (in Chinese).

Kim J.J., Ogata T., Mine K., Takenaka T., Sakuma M., and Seo Y.N. (1993) Human skeletal remains from Yeanri site, Kimhae, Korea. Archaeological Research Report of the University Museum, Pusan National University, 15: 281-334.

Kintaka K. (1928) Anthropologische Untersuchungen über das Skelett der Yoshiko-Steinzeitmenschen. 1, Der Schädel. The Journal of the Anthropological Society of Tokyo, 43 (supplements): 497-736.

Kiyono K. and Miyamoto H. (1926) Anthropologische Untersuchungen über das Skelett der Tsukumo-Steinzeitmenschen. 2, Der Schädel. The Journal of the Anthropological Society of Tōkyō, 41: 95-140, 151-208.

Kondo O. (1993) Morphometric data on the skulls of Ubayama shell-mounds. Anthropological Science, 101: 333-360.

Liu H. and Sun D. (1996) A survey on the distribution and current situation of Hanging-Coffin in Yunnan Province. Yunnan Geographic Environment Research, 8: 66-71 (in Chinese).

Liu H., Liu X., Ji X., and Yu T. (2001) The archaeological studies of Guanmuyan Hanging Coffins, Chang'an Township, Weixin County, Yunnan Province. Yunnan Geographic Environment Research, 13: 86-92 (in Chinese).

Liu W., Yang M., and Wang Y. (1991) Study of metric traits and geographical variations of modern Chinese skulls. Acta Anthropologica Sinica, 10: 96-106 (in Chinese).

Matsumura H., Cuong N.L., Thuy N.K., and Anezaki T. (2001) Dental morphology of the Early Hoabinian, the Neolithic Da But and the Metal Age Dong Son civilized peoples in Vietnam. Zeitschrift fur Morphologie und Anthropologie, 83: 5973.

Meindl R.S. and Lovejoy C.O. (1985) Ectocranial suture closure: a revised method for the determination of skeletal age at death based on the lateral-anterior sutures. American Journal of Physical Anthropology, 68: 57-66.

Molnar S. (1971) Human tooth wear, tooth function and cultural variability. American Journal of Physical Anthropology, 34: $175-190$.

Morant G.M. (1923) A first study of the Tibetan skull. Biometrika, 14: 193-260.

Nakahashi T. and Nagai M. (1989) Keishitsu (Bone Morphology of Yayoi People). In: Nagai M., Nasu T., Kanaseki T., and Sahara M. (eds.), Yayoi Bunka no Kenkyu, Volume 1. Yuzankaku shuppan, Tokyo, pp. 23-51 (in Japanese).

Nakahashi T. and Li M. (2002) Ancient People in the Jiangnan Region, China: Anthropological Study on the Origin of the Yayoi People in Northern Kyushu. Kyushu University Press, Fukuoka.

Pietrusewsky M. (1994) Pacific-Asian relationships: a physical anthropological perspective. Oceanic Linguistics, 33: 407429.

Pietrusewsky M., Li Y., Shao X., and Quyen N.Q. (1992) Modern and near modern populations of Asia and the Pacific: a multivariate craniometric interpretation. In: Akazawa T., Aoki K., and Kimura T. (eds.), The Evolution and Dispersal of Modern Humans in Asia. Hokusen-sha, Tokyo, pp. 531-558.

Ruhlen M. (1994) On the Origin of Languages: Studies in Linguistic Taxonomy. Stanford University Press, Stanford.

Shima G. (1933) Anthropological study of the Chinese skull obtained from the suburbs of Fushun, Manshuria. The Journal of the Anthropological Society of Tokyo, 48: 423-453.

Suzuki H. (1969) Microevolutional changes in the Japanese population from the prehistoric age to the present-day. Journal of the Faculty of Science, University of Tokyo, Section 5, Anthropology, Volume 3, pp. 279-309.

Suzuki H. (1982) Skulls of the Minatogawa Man. In: Suzuki H. and Hanihara K. (eds.), The Minatogawa Man. University of Tokyo Press, Tokyo, pp. 7-50.

Takenaka M. (1994) Morphological traits of crania in modern Kyongsangnam-do Koreans. Acta Anatomica Nipponica, 69: 645-660.

Turner C.G. II (1987) Late Pleistocene and Holocene population history of East Asia based on dental variation. American Journal of Physical Anthropology, 73: 305-321.

Tildesley M.L. (1921) A first study of the Burmese skull. Biometrika, 13: 176-260.

Wang L. (1986) Secular change and geographical variation in Chinese Neolithic and modern inhabitants: a statistical study of cranial metric traits. Acta Anthropologica Sinica, 5: 243-258 (in Chinese).

Wang L. and Sun F. (1988) A study on the skulls from Taiyuan, Shanxi. Acta Anthropologica Sinica, 7: 206-214 (in Chinese).

Yamaguchi B. (1973) Facial flatness measurements of the Ainu and Japanese crania. Bulletin of National Science Museum, 16: 161-171.

Yamaguchi B. and Huang X. (1995) Studies on the Human Skeletal Remains from Jiangnan, China. National Science Museum Monographs, No. 10, National Science Museum, Tokyo.

Zhang Z. (1990) The Nationalities Archaeology of Southwest of China. Yunnan People's Publication House, pp. 45-65 (in Chinese). 
Appendix 1. Cranial measurements of the Washi and Longma skulls

\begin{tabular}{|c|c|c|c|}
\hline & & Washi (male) & Longma (male) \\
\hline 1 & $\begin{array}{l}\text { Maximum cranial length, } \\
\text { g-op (GOL) }\end{array}$ & 182.0 & 181.0 \\
\hline 5 & Basal length, $\mathrm{b}-\mathrm{n}(\mathrm{BNL})$ & 97.5 & 101.0 \\
\hline 8 & $\begin{array}{l}\text { Maximum cranial breadth, } \\
\text { eu-eu (XCB) }\end{array}$ & 145.5 & 138.0 \\
\hline 9 & Minimum frontal breadth & 90.5 & 98.9 \\
\hline 7 & $\begin{array}{l}\text { Foramen magnum length, } \\
\text { ba-o }\end{array}$ & 35.8 & 33.5 \\
\hline 16 & Foramen magnum breadth & 28.0 & 28.0 \\
\hline 17 & $\begin{array}{l}\text { Basi-bregmatic height, } \\
\text { ba-b (BBH) }\end{array}$ & 142.0 & 139.0 \\
\hline 21 & Auricular height, po- $-\mathrm{v}$ & 122.2 & 114.0 \\
\hline 23 & $\begin{array}{l}\text { Horizontal circumference } \\
(\mathrm{g}, \mathrm{op})\end{array}$ & 517.0 & 511.0 \\
\hline 24 & Transverse arc, po-b-po & 330.0 & 311.0 \\
\hline 25 & Total sagittal arc, $n-0$ & 388.0 & 388.0 \\
\hline 26 & Frontal sagittal arc, $n-b$ & 126.0 & 129.0 \\
\hline 27 & Parietal sagittal arc, b-1 & 134.0 & 126.0 \\
\hline 28 & Occipital sagittal arc, $1-0$ & 124.0 & 122.0 \\
\hline 29 & Frontal sagittal chord, $\mathrm{n}-\mathrm{b}$ & 113.0 & 111.1 \\
\hline 30 & Parietal sagittal chord, b-1 & 120.4 & 113.6 \\
\hline 31 & Occipital sagittal chord, $1-\mathrm{o}$ & 105.9 & 104.7 \\
\hline 40 & $\begin{array}{l}\text { Facial profile length, } \\
\text { pr-ba (BPL) }\end{array}$ & 90.6 & 97.9 \\
\hline 45 & $\begin{array}{l}\text { Bizygomatic breadth, } \\
\text { zy-zy (ZYB) }\end{array}$ & 131.2 & $(134.8)^{\mathrm{a}}$ \\
\hline 46 & $\begin{array}{l}\text { Bimaxillary breadth, } \\
\mathrm{zm}-\mathrm{zm}\end{array}$ & 95.6 & - \\
\hline 47 & Total facial height, $n-$ gn & - & 112.5 \\
\hline 48 & $\begin{array}{l}\text { Upper facial height, } \\
\text { n-pr (NPH) }\end{array}$ & 64.8 & 62.5 \\
\hline & Upper facial height, $\mathrm{n}-\mathrm{sd}$ (av) & 68.4 & 67.0 \\
\hline 50 & $\begin{array}{l}\text { Anterior interorbital breadth, } \\
\mathrm{mf}-\mathrm{mf}\end{array}$ & 18.1 & 20.6 \\
\hline 51 & $\begin{array}{l}\text { Orbital breadth, mf-ek (L) } \\
\text { (R) }\end{array}$ & $\begin{array}{l}42.3 \\
43.0\end{array}$ & $\begin{array}{l}43.2 \\
-\end{array}$ \\
\hline $51 \mathrm{a}$ & $\begin{array}{l}\text { Orbital breadth, d-ek (OBB) } \\
\text { (L) } \\
\text { (R) }\end{array}$ & $\begin{array}{l}(41.1)^{\mathrm{a}} \\
(40.7)^{\mathrm{a}}\end{array}$ & $\begin{array}{l}40.0 \\
-\end{array}$ \\
\hline 52 & $\begin{array}{l}\text { Orbital height }(\mathrm{OBH})(\mathrm{L}) \\
(\mathrm{R})\end{array}$ & $\begin{array}{l}33.4 \\
32.9\end{array}$ & 33.0 \\
\hline 54 & Nasal breadth (NLB) & 25.6 & 28.0 \\
\hline 55 & Nasal height, n-ns (NLH) & 49.9 & 49.4 \\
\hline 60 & $\begin{array}{l}\text { Maxillo-alveolar length, } \\
\text { pr-alv }\end{array}$ & 47.6 & 56.3 \\
\hline 61 & $\begin{array}{l}\text { Maxillo-alveolar breadth, } \\
\text { emk-emk }\end{array}$ & 60.3 & 57.3 \\
\hline 62 & Palatal length, ol-sta & 38.8 & 44.8 \\
\hline 63 & $\begin{array}{l}\text { Palatal breadth, } \\
\text { enm-enm (M2) }\end{array}$ & 38.1 & 31.2 \\
\hline 72 & $\begin{array}{l}\text { Facial profile angle, } \\
\text { n-pr and FH }\end{array}$ & 84.0 & 80.0 \\
\hline 73 & $\begin{array}{l}\text { Midfacial profile angle, } \\
n-n s \text { and FH }\end{array}$ & 85.0 & 81.5 \\
\hline 74 & $\begin{array}{l}\text { Alveolar profile angle, } \\
\text { ns-pr and FH }\end{array}$ & 80.0 & 67.0 \\
\hline
\end{tabular}

Appendix 1. (continued)

\begin{tabular}{|c|c|c|c|}
\hline $8: 1$ & Cranial length-breadth index & 79.95 & 76.2 \\
\hline $17: 1$ & Cranial length-height index & 78.0 & 76.8 \\
\hline $17: 8$ & Cranial breadth-height index & 97.6 & 100.7 \\
\hline $9: 8$ & Transverse frontoparietal index & 62.2 & 71.7 \\
\hline $40: 5$ & Gnathic index & 92.9 & 96.9 \\
\hline $48: 45$ & $\begin{array}{l}\text { Kollmann's upper facial index } \\
\text { pr }\end{array}$ & $\begin{array}{l}49.4 \\
52.1\end{array}$ & $\begin{array}{c}(46.4)^{\mathrm{a}} \\
(497)^{\mathrm{a}}\end{array}$ \\
\hline $52: 51$ & $\begin{array}{l}\text { Orbital index (L) } \\
(\mathrm{R})\end{array}$ & $\begin{array}{l}79.0 \\
76.5\end{array}$ & 76.4 \\
\hline $54: 55$ & Nasal index & 51.3 & 56.7 \\
\hline $61: 60$ & Maxillo-alveolar index & 126.7 & 101.8 \\
\hline $63: 62$ & Palatal index & 98.2 & 69.6 \\
\hline $48: 17$ & $\begin{array}{l}\text { Vertical craniofacial index pr } \\
\text { sd (av) }\end{array}$ & $\begin{array}{l}45.6 \\
48.2\end{array}$ & $\begin{array}{l}45.0 \\
48.2\end{array}$ \\
\hline \multicolumn{4}{|c|}{ Facial flatness measurements } \\
\hline & Frontal chord & 95.4 & - \\
\hline & Frontal subtense & 16.9 & - \\
\hline & Frontal index & 17.7 & - \\
\hline & Simotic chord & 6.2 & 10.0 \\
\hline & Simotic subtense & 3.5 & 2.5 \\
\hline & Simotic index & 55.7 & 25.2 \\
\hline & Zygomaxillary chord & 93.3 & - \\
\hline & Zygomaxillary subtense & 24.4 & - \\
\hline & Zygomaxillary index & 26.2 & - \\
\hline \multicolumn{4}{|c|}{ Radius measurements (from Howells) } \\
\hline & Nasion radius (NAR) & 93.5 & 94.0 \\
\hline & Subspinale radius (SSR) & 93.0 & 95.5 \\
\hline & Prosthion radius (PRR) & 97.5 & 101.5 \\
\hline & Dacryon radius (DKR) & 86.0 & 84.0 \\
\hline & Zygoorbitale radius (ZOR) & 81.5 & 84.0 \\
\hline & Frontomalare radius (FMR) & 77.5 & 76.0 \\
\hline & Ectoconchion radius (EKR) & 71.0 & 72.5 \\
\hline & Zygomaxillare radius (ZMR) & 68.0 & 73.5 \\
\hline & Molar alveolus radius (AVR) & 78.5 & 82.0 \\
\hline
\end{tabular}

${ }^{\text {a }}$ Estimated value in parenthesis.

Appendix 2. Cranial non-metric traits in Washi and Longma skulls

\begin{tabular}{|c|c|c|c|c|}
\hline & \multicolumn{2}{|c|}{$\begin{array}{l}\text { Washi } \\
\text { (male) }\end{array}$} & \multicolumn{2}{|c|}{$\begin{array}{c}\text { Longma } \\
\text { (male) }\end{array}$} \\
\hline & $\mathrm{r}$ & 1 & $\mathrm{r}$ & \\
\hline 1 Metopism $(>1 / 2)$ & & & & 0 \\
\hline 2 Supraorbital nerve groove $(>10 \mathrm{~mm})$ & 0 & 0 & 0 & \\
\hline 3 Supraorbital foramen & 0 & 0 & 0 & 0 \\
\hline 4 Ossicle at lambda & & & & 0 \\
\hline 5 Biasterionic suture $(>10 \mathrm{~mm})$ & 0 & 0 & 0 & 0 \\
\hline 6 Occipito-mastoid wormians and ossicle & 0 & 0 & 0 & \\
\hline 7 Pariet & 0 & 0 & 0 & \\
\hline 8 Condyl & 1 & 0 & 1 & \\
\hline 9 Third & & & & 0 \\
\hline 10 Paraco & 0 & 0 & 0 & 0 \\
\hline 11 Нуро & 0 & 0 & & \\
\hline 12 Foram & 0 & 0 & 0 & \\
\hline 13 Foram & 0 & 0 & 0 & 0 \\
\hline 14 Foram & 1 & 0 & 1 & \\
\hline 15 Medial palatine canal $b$ & 0 & 0 & 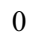 & \\
\hline 16 Aura & 0 & 0 & 0 & \\
\hline omatic suture (> $5 \mathrm{~mm}$ ) & 0 & 0 & t & 0 \\
\hline 18 Mylohyoid bridging & 1 & 1 & 0 & 0 \\
\hline 19 Mandibular torus & 1 & 1 & 0 & \\
\hline 20 Juglar foramen bridgin & 0 & 0 & 0 & \\
\hline 21 Sagittal groove left & & & & 0 \\
\hline 22 Palatine torus & & & & 0 \\
\hline
\end{tabular}

0 , absent; 1, present; /, unobservable. 